\title{
Characterizing Juvenile Chinook Salmon Residency and Early Growth in the Lower Fraser River Estuary
}

\author{
Lia Chalifour ${ }^{1}$, David C. Scott ${ }^{2}$, Misty MacDuffee ${ }^{2}$, John F. Dower ${ }^{1}$, Terry D. Beacham ${ }^{3}$, and Julia K. Baum ${ }^{1}$ \\ ${ }^{1}$ University of Victoria, 2800 Finnerty Rd., Victoria, BC, V8P 5C2, Canada \\ ${ }^{2}$ Raincoast Conservation Foundation, 2238 Harbour Rd., Sidney, BC, V8L 2P6, Canada \\ ${ }^{3}$ Fisheries and Oceans Canada, Pacific Biological Station, 3190 Hammond Bay Road, Nanaimo, BC, V9T 6N7, \\ Canada
}

Keywords: Chinook salmon, subyearling migrant, estuary, otolith daily growth, early marine growth

The Harrison River is a tributary of the lower Fraser River system which produces the highest proportion of fall-run, subyearling migrant Chinook salmon (Oncorhynchus tshawytscha) in the Salish Sea (Fraser et al. 1982; Murray and Rosenau 1989). Subyearling migrant Chinook, which emigrate to estuarine and marine waters within the first year, may be more dependent on nearshore habitats than yearling migrants during their first year of ocean residency (Weitkamp et al. 2014). Some cohorts emigrate as early as first emergence from their eggs as fry in March, while others arrive in the estuary well into their first year, in June and July (Levings et al. 1986; Healey 1991). Previous studies have inferred salmon stock composition based on catch timing, fork length and known life history strategies (Levy and Northcote 1982). Current technology allows us to precisely identify stock groups using tissue samples and genetic analysis (Beacham et al. 2011). Otolith studies can give a detailed picture of the life history of individual fishes, including quantitative measures of residency in different water bodies (Miller et al. 2010; Volk et al. 2010). Using a combination of genetic and otolith analyses, we assessed the stock-specific utilization of three habitat types in the lower Fraser estuary by emigrating Chinook.

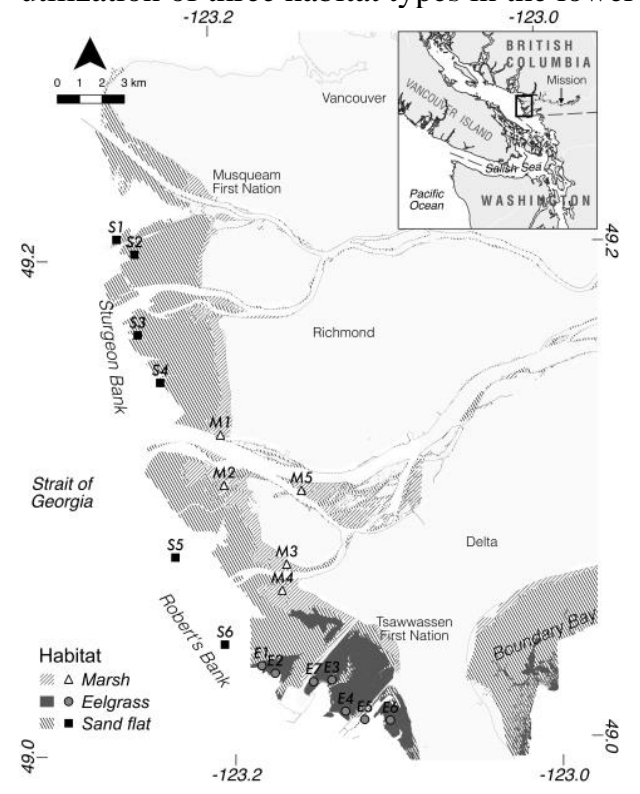

Fig. 1. Sites sampled in 2016 and 2017 in three distinct habitats within the Fraser River estuary, British Columbia, Canada: five marsh sites (white triangles; M1-M5), six sand flat sites (black squares; S1-S6), and six eelgrass sites (grey circles; E1-E6). All sites were sampled each year, with the exception of E6, which was replaced by eelgrass site 7 (E7) in 2017.

Table 1. Salmon catch by habitat in the Fraser River estuary.

\begin{tabular}{lllllll}
\hline & 2016 & & & 2017 & & Eelgrass \\
\cline { 2 - 7 } Species (total N) & Marsh & Eelgrass & Sand flat & Marsh & flat \\
\hline Chinook $(1,193)$ & 435 & 19 & 61 & 500 & 129 & 49 \\
Chum $(1,088)$ & 120 & 4 & 5 & 394 & 464 & 101 \\
Sockeye $(147)$ & 17 & 6 & 14 & 5 & 103 & 2 \\
Pink (43) & 39 & 1 & 3 & 0 & 0 & 0 \\
Coho (4) & 4 & 0 & 0 & 0 & 0 & 0 \\
Steelhead (2) & 0 & 0 & 0 & 0 & 2 & 0 \\
TOTAL & $\mathbf{6 1 5}$ & $\mathbf{3 0}$ & $\mathbf{8 3}$ & $\mathbf{8 9 9}$ & $\mathbf{6 9 8}$ & $\mathbf{1 5 2}$ \\
\hline
\end{tabular}




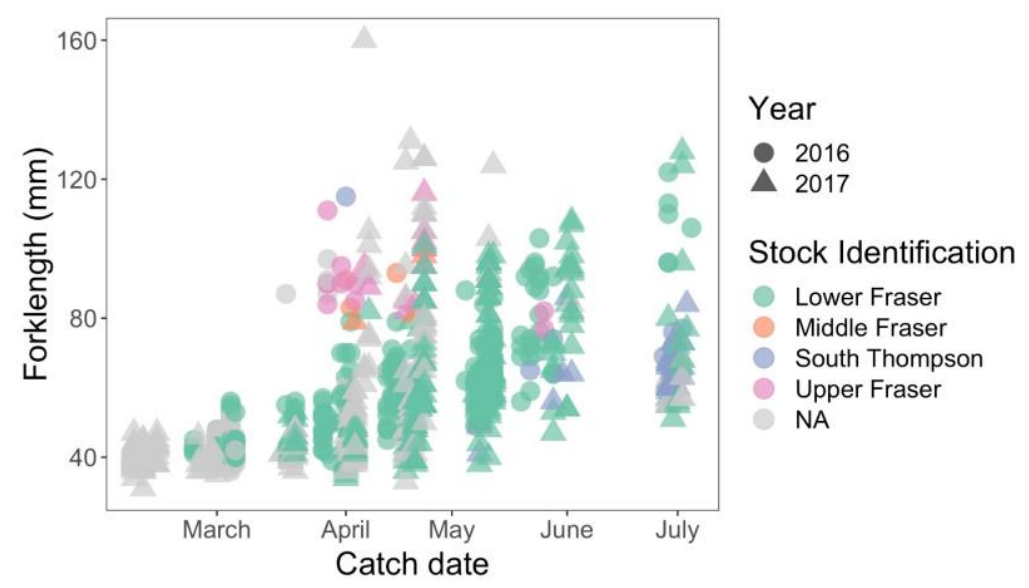

Fig. 2. Catch day and size of juvenile Chinook salmon in the Fraser River estuary for 2016 (circles) and 2017 (triangles). Each marker denotes a fish, and colours correspond to stock identification, grouped by region. Lower Fraser (green) includes fish identified as 'Harrison' and 'W_Chilliwack'; Middle Fraser (orange) includes 'Horsefly' and 'L_Cariboo'; South Thompson (blue) includes 'Deadman', 'L_Thompson', 'Little_R', and 'South_Thom'; and Upper Fraser (pink) includes 'Goat', 'Horsey', 'Indianpoint', 'Morkill', 'Nechako', 'Slim_C', 'Stuart', and 'Torpy'. Fish that were measured but not sampled for genetic stock identification are grey.

In 2016 and 2017, we surveyed 17 sites across the lower estuary (Fig. 1), sampling 2,477 juvenile Chinook salmon and collecting 836 tissue samples for genetic stock identification. We caught the majority of all salmon in brackish marsh habitat in both years $(n=1,514 / 2,477 ; 61 \%$; Table 1$)$, despite anomalous flow and temperature conditions in 2016 (Chandler et al. 2017), and annual variation in escapement. In 2016 and 2017, we caught 733 and 1749 salmon, the majority of which were Chinook Salmon (515 and 678), respectively. Overall, we captured juvenile Chinook from 18 different populations, with stream-type populations generally captured in very low numbers. Catch composition was dominated by subyearling migrants identified as Harrison/Chilliwack $(n=701)$, arriving the earliest near the end of March, and present the longest until mid-July in 2016 and mid-June in 2017 (Fig. 2). We retained a subsample of these lower Fraser River juveniles from 2016 to assess entry timing and estuarine growth prior to capture using visual and chemical analyses of the otoliths via LA-ICP-MS ( $n=98$ otoliths; preliminary results reported for $n=50$ otoliths).

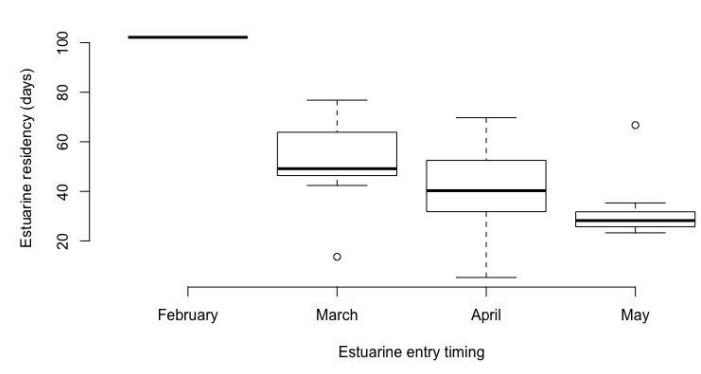

Fig. 3. Juvenile Chinook estuarine residency prior to capture by month of estuarine entry. Estuarine entry point was determined using chemical analysis of sagittal otoliths via LA-ICP-MS. Daily growth and number of days after entry were subsequently determined using visual measurements of the otoliths.

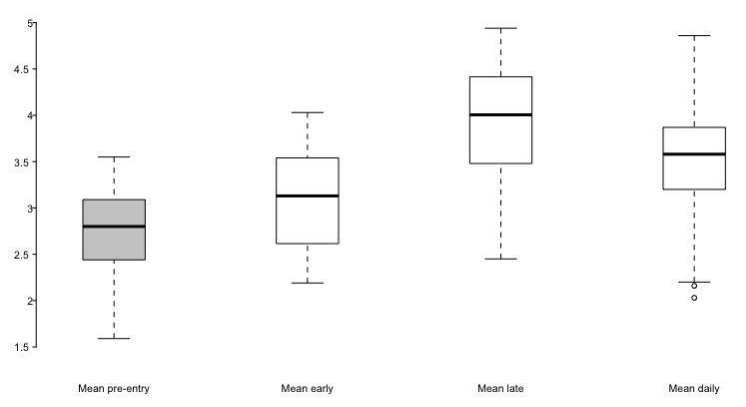

Fig. 4. Mean daily otolith growth of juvenile Chinook for the fresh water period just prior to estuarine entry ('Mean pre-entry'), the first 7-14 days after entry ('Mean early'), the last 7-14 days prior to capture ('Mean late'), and the overall mean estuarine growth ('Mean daily'). Box and whisker plots depict the median (black line), $25^{\text {th }}$ and $75^{\text {th }}$ quartiles (box), and range of values (whiskers) for each group, with points past the whiskers depicting extreme measurements outside of the standardized interquartile range.

Most lower Fraser Chinook entered the estuary in March and April, with fish that entered earlier spending a longer period in the estuary prior to capture (Fig. 3). The majority of fish appeared to reside in the estuary for 30-50 days $(n=23 / 50)$, with some captured after fewer than 20 days $(n=4 / 50)$, and one fish 102 days after estuarine entry. As expected, we found that daily growth rates improved over time (Fig. 4), as fish grew and presumably experienced better foraging success. In our preliminary data, we did not find a significant difference in daily growth rates among fish cohorts by estuarine entry timing (Fig. 5), indicating that the broad range of emigration timing to 
the estuary may result in similar growth. There is a slight trend toward better growth in summer months (May, June), which may align with greater food production in the estuary.
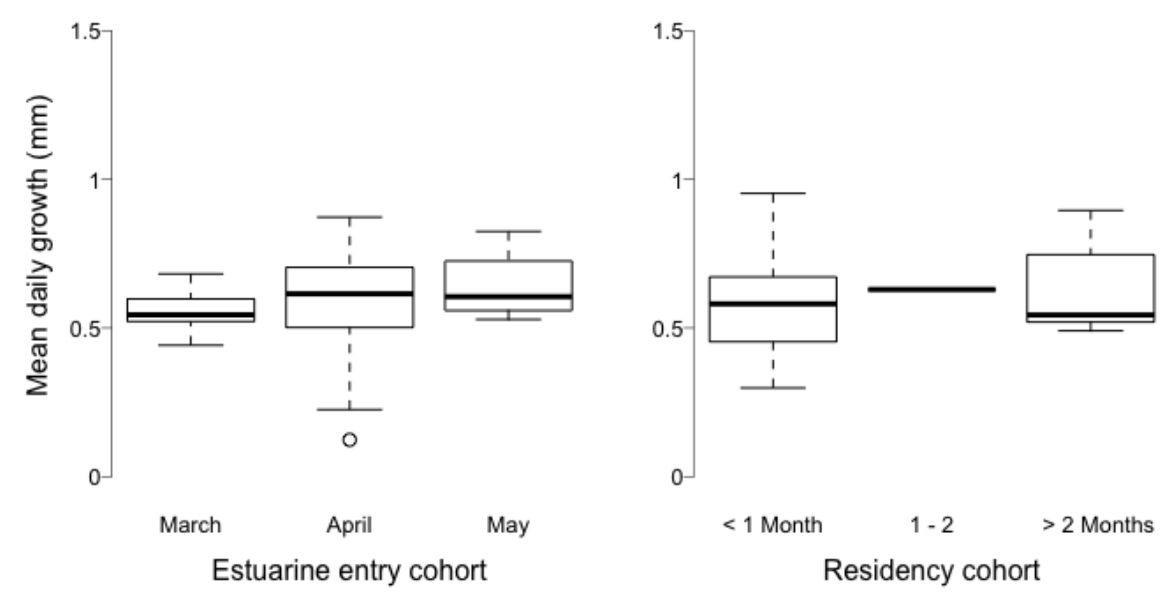

Fig. 5. Mean daily growth in fork length for cohorts of Chinook that enter the Fraser River estuary in different months (left panel) and reside in the estuary for varying time periods (right panel). Box and whisker plots depict the median (black line), $25^{\text {th }}$ and $75^{\text {th }}$ quartiles (box), and range of values (whiskers) for each group, with points past the whiskers depicting extreme measurements outside of the standardized interquartile range.

Lower Fraser River subyearling migrant Chinook appear to have a strong portfolio of varying life history strategies when it comes to ocean entry. A variety of life history strategies may make Chinook populations more resilient to shifts in climate, flow rates, food availability and other stressors (Phillis et al. 2018). This study clarifies the entry timing, minimum residency period, and daily growth rates for lower Fraser River Chinook salmon. We recommend that future studies focus on linking early marine growth to adult returns to elucidate the impacts of estuarine residency on survival.

\section{REFERENCES}

Beacham, T.D., K.L. Jonsen, J. Supernault, M. Wetklo, L. Deng, and N. Varnavskaya. 2011. Pacific Rim population structure of Chinook salmon as determined from microsatellite analysis. Trans. Am. Fish. Soc. 135: 1604-1621.

Chandler, P.C., S.A. King, and J. Boldt (Editors). 2017. State of the physical, biological and selected fishery resources of Pacific Canadian marine ecosystems in 2016. Can. Tech. Rep. Fish. Aquat. Sci. 3225:243 +vi p.

Fraser, F.J, P.J. Starr, and A.Y. Fedorenko. 1982. A review of the Chinook and coho salmon of the Fraser River. Can. Tech. Rep. Fish. Aquat. Sci: 1-130.

Healey, M.C. 1991. Life History of Chinook Salmon. In Pacific salmon life histories. Edited by C. Groot andL. Margolis. Univ. British Columbia Press, Vancouver. pp. 311-393.

Levings, C.D, C.D. McAllister, and B.D. Chang. 1986. Differential use of the Campbell River estuary, British Columbia, by wild and hatchery-reared juvenile Chinook salmon. Can. J. Fish. Aquat. Sci. 4: 1386-1397.

Levy, D.A., and T.G. Northcote. 1982. Juvenile salmon residency in a marsh area of the Fraser River estuary. Can. J. Fish. Aquat. Sci. 39: 270-276.

Miller, J.A., A. Gray, and J. Merz. 2010. Quantifying the contribution of juvenile migratory phenotypes in a population of Chinook salmon Oncorhynchus tshawytscha. Mar. Ecol. Prog. Ser. 408: 227-240.

Murray, C.B., and M.L. Rosenau. 1989. Rearing of juvenile Chinook salmon in nonnatal tributaries of the lower Fraser River, British Columbia. Trans. Am. Fish. Soc. 118: 284-289.

Phillis, C.C., A.M. Sturrock, R.C. Johnson, and P.K. Weber. 2018. Endangered winter-run Chinook salmon rely on diverse rearing habitats in a highly altered landscape. Biol. Conserv. 217: 358-362.

Volk, E.C., D.L. Bottom, K.K. Jones, and C.A. Simenstad. 2010. Reconstructing juvenile Chinook salmon life history in the Salmon River estuary, Oregon, using otolith microchemistry and microstructure. Trans. Am. Fish. Soc. 139: 535-549.

Weitkamp, L.A., G. Goulette, J. Hawkes, M. O’Malley, and C. Lipsky. 2014. Juvenile salmon in estuaries: Comparisons between North American Atlantic and Pacific salmon populations. Rev. Fish Biol. Fish. 24: 713-736. 